\title{
INVESTIGATIONS ON ECONOMIC INJURY LEVEL AND RELATIONSHIP BETWEEN TRAP CATCH AND CROP LOSS IN MANDARIN ORCHARDS BY INFESTATION OF THE MEDITERRANEAN FRUIT- FLY Ceratitis capitata (WIED.) (DIPTERA: TEPHRITIDAE) IN EGYPT
}

\author{
AIDA M. EL-HAKIM, T.S. EL-ABBASSI AND A.M.Z. MOSALLAM
}

Plant Protection Research Institute, ARC, Dokki, Giza

(Manuscript received 19 October 2008)

\begin{abstract}
Two experimental designs were carried out at Fayoum Governorate during mature fruit seasons of 2006 and 2007 to establish different levels of infestation on the economic injury level of the Mediterranean fruit-fly (Medfly) Ceratitis capitata (Wied.). In the first trial, four mandarin trees at different levels of infestation were surrounded by muslin cages constructed by wooden frames. Sticky traps baited with trimedlure were hung on each tree for evaluating adult fly density and the relationship between trap catch and infestation percent, total of living stages and crop loss. The second trial was carried out to establish a range of infestation levels across experimental field plots of mandarin using different insecticide treatments to evaluate the relationship between $C$. capitata density and the abovementioned parameters. High levels of $C$. capitata adults in trap catch were associated with significant reductions in fruit yield. The loss in mandarin yield was evaluated at different levels of infestation. High yield loss was obtained ( $903 \$ /$ feddan) in mandarin plots when no control practices were applied.
\end{abstract}

\section{INTRODUCTION}

The Mediterranean fruit-fly Ceratitis capitata (Wied.) (Diptera: Tephritidae) is considered one of the most serious pest worldwide infesting fruits of $>300$ plant species (Liquido et al., 1991). It has also an expanding geographical distribution. In Egypt, this pest was early recorded in 1904 (Compere, 1912). It causes considerable damage and inflicts significant economic losses in fruit orchards (Hafez \& Fares, 1967).

For controlling Medfly, growers rely use insecticide applications on a regular bases regardless to the adult density. This technique often results in improper time or unnecessary insecticide applications.

Economic thresholds and economic injury levels are important components in an integrated pest management programes and are useful for determining the application timing of pesticides. 
The objective of this study was to find out an easy and not time consuming method to determine the economic injury level caused by Medfly in mandarin orchards and to establish a relationship between trapped adult density and fruit damage.

\section{MATERIALS AND METHODS}

During mature fruit seasons of 2006 and 2007, trials to evaluate the economic injury level of Medfly infestation in mandarin orchards and relationship between density of adult fly and fruit injury were conducted at Fayoum Governorate. Two experimental designs were evaluated:

\section{Levels of Medfly Infestation in Field Cages}

The first trial was conducted during fruit maturity (November, December, 2006 and January, 2007). Four mandarin trees naturally infested by C. capitata at different degrees (low, medium, high and very high) were chosen. Each selected tree was covered by unexpensive and easy to construct muslin cages using suitable wooden frames.

A sticky trap (Harris et al., 1971) baited with trimedlure (tetra-butyl-4- [and 5] chloro-2-methyl-cyclohexane-1-carboxylate) was hung on each tree at the beginning of mature fruit season, and checked weekly where flies were counted and recorded (catch/trap/week).

Samples of mandarin fruits (20 from each tree) were collected weekly at random and checked in the laboratory for estimating infestation percent and counting the living forms i.e. eggs and larvae. Fallen fruits under the tree were collected weekly and inspected also in the laboratory.

\section{Insecticide Treatments to Estimate Different Levels of Medfly Infestation} in the Open Orchard

A range of infestation levels of the Mediterranean fruit-fly were established across experimental field plots of mandarin by varying insecticide treatments to evaluate the relationship between Medfly density (catch/trap/day) and crop production during mature fruit season of 2007 (October - November). Malathion 57\% EC [0,0-dimethyl-S-(1,2-biscarbathoxy ethyl) phosphordithioate] bait-spray was used to obtain complete sound fruits, very low, low, medium, high and very high infestation.

Four feddans of mandarin orchard were devided into 8 plots, nearly half feddan each. The first plot was partially sprayed by malathion $57 \%$ EC ( $1 / 2$ litre $)+$ buminal (protein hydrolyzate) (one litre) and 18.5 litre water $(250 \mathrm{ml}$ solution for each tree). The second plot was treated as one row sprayed with the same concentration and leaving the other row. The third was sprayed at every third row. The fourth was 
sprayed at every fourth row. The fifth at every fifth row. The sixth at every sixth row. The seventh was left untreated.

At the beginning of the experiment, sticky traps baited with trimedlure were hung in each plot and attracted flies were counted weekly.

Samples of 20 fruits were randomly picked from different directions of three selected trees at each plot (level of infestation) and taken to the laboratory to determine percent of infestation, number of living stages of Medfly (eggs, first, second and third larval instars).

Fallen fruits under trees were collected, transferred to laboratory and checked for Medfly infestation to estimate crop loss.

Analysis of data was statistically calculated according to Snedecor (1991).

\section{RESULTS AND DISCUSSION}

\section{Levels of Medfly Infestation in Field Cages:}

Population density of Medfly in field cages was classified to low, medium, high and very high (Table, 1). Number of flies at the beginning of the season was considered a good predictor for the expected population density in the whole season to establish a relationship between mean catch per trap per week (CTW), mean infestation percent, total number of living stages and total of fruit loss. Statistical analysis between abovementioned parameters against density of Medfly calculated according to Snedecor, 1991 proved that the relationship between mean number of captured flies per trap per week and infestation percent during the season was positive and significant $(r=+0.97)$, between mean catch per trap per week and total of living stages was positive and not significant $(r=+0.55)$, between mean catch per trap per week and crop loss was positive and significant $(r=+0.99)$.

The same Table shows positive and insignificant relationship between fly density at the beginning of mature fruit season and both mean percent of infestation $(r=+0.93)$ and total number of living stages $(r=+0.66)$. While, the relationship was positive and significant with total crop loss $(r=+0.99)$. in general, the higher and population density of adult fly, the increment of the abovementioned parameters, and during the second half of mature fruit season reveres was true, where the tested parameters increased as the density decreased (Fig., 1). These unsatisfactory results were because of the removal of the fallen infested fruits from the isolated field cages, and this did not allow reinfestation and building up a second generation inside cage.

\section{Insecticide Treatments to Estimate Different Levels of Medfly Infestation:}

In an open mandarin orchard of which was devided into 8 plots, each $1 / 2$ feddan; levels of infestation was established through an insecticide treatment of malathion bait-spray. It was clear that as the density of adult fly of $C$. capitata 
increased, the other parameters (mean infestation percent, total of living stages and total of crop loss) increased too (Fig., 2). The relationship between density of adult fly assessed as captured flies/trap/day (CTD) during mature fruit season and mean infestation percent, total of living forms and total of crop loss per tree was positive and not significant ( $r=+0.72,+0.62$ and +0.66 , respectively) (Table, 2$)$. This could be attributed to emigration of adult fly from one plot to another and because of the distance between plots was at the range of the flight ability of the fly.

The same Table also shows that the relationship between catch/trap/day at the beginning of the mature fruit season and the abovementioned parameters were highly significant and positive $(r=+0.904,+0.896$ and +0.903 , respectively).

Total crop loss per feddan (200 trees) increased gradually with the increase of infestation at medium, high and very high levels of infestation (considering $1 \mathrm{Kg}=1.5$ L.E.), $743 \mathrm{Kg}$ (1115 L.E.), $933 \mathrm{Kg}$ (1399.5 L.E.), $900 \mathrm{Kg}$ (1350 L.E.), respectively. The crop loss in untreated orchard of mandarin by Mediterranean fruit-fly infestation at Fayoum Governorate was $3310 \mathrm{Kg}$ (4965 L.E. approximately equal $903 \$, 1 \$=5.50$ L.E.).

Table 1. Relationship between catch/trap/week and mean infestation percent, total of living stages and total of fruit loss in mandarin orchard due to infestation by Ceratitis capitata in field cage experiment during 2006/2007 season.

\begin{tabular}{|l|c|c|c|c|c|c|}
\hline \multicolumn{2}{|c|}{$\begin{array}{c}\text { Infestation } \\
\text { level }\end{array}$} & $\begin{array}{c}\text { Catch/trap at the } \\
\text { beginning of the } \\
\text { season }\end{array}$ & $\begin{array}{c}\text { Mean catch/ } \\
\text { trap/week }\end{array}$ & $\begin{array}{c}\text { Mean fruit } \\
\text { infestation (\%) }\end{array}$ & $\begin{array}{c}\text { Total of } \\
\text { living forms }\end{array}$ & $\begin{array}{c}\text { Total of fruit } \\
\text { loss/tree }\end{array}$ \\
\hline Low & (Cage I) & 2 & 10.7 & 12.1 & 107 & 48 \\
Medium & (Cage II) & 30 & 18.5 & 11.4 & 121 & 48 \\
High & (Cage III) & 52 & 23.5 & 11.4 & 131 & 50 \\
Very high & (Cage IV) & 171 & 91.1 & 18.1 & 129 & 58 \\
\hline
\end{tabular}

Table 2. Relationship between catch/trap/day and mean of infestation percent, living stages and fruit loss in mandarin orchard due to infestation by Ceratitis capitata in open orchard during 2007 season.

\begin{tabular}{|l|c|c|c|c|c|c|}
\hline Infestation level & $\begin{array}{c}\text { Catch/trap/ day at } \\
\text { the beginning of the } \\
\text { season }\end{array}$ & $\begin{array}{c}\text { Mean } \\
\text { catch/ } \\
\text { trap/day }\end{array}$ & $\begin{array}{c}\text { Mean } \\
\text { infestation \% }\end{array}$ & $\begin{array}{c}\text { Mean of living } \\
\text { forms/tree }\end{array}$ & $\begin{array}{c}\text { Mean of } \\
\text { fruit-loss } \\
\text { tree }\end{array}$ & $\begin{array}{c}\text { Loss/ } \\
\text { feddan } \\
(\mathrm{Kg})\end{array}$ \\
\hline Sound fruits & 4.6 & 22.7 & 0.0 & 0.0 & 0.0 & 0.0 \\
Very low & 14.7 & 24.0 & 1.57 & 21.4 & 18.7 & 62.3 \\
Low & 21.7 & 28.0 & 2.65 & 36.7 & 14.3 & 476.0 \\
Medium & 19.4 & 30.5 & 3.37 & 54.0 & 22.3 & 743.3 \\
High & 34.6 & 36.1 & 6.15 & 67.3 & 28.0 & 933.3 \\
Very high & 16.1 & 37.0 & 6.18 & 56.0 & 27.0 & 900.0 \\
Untreated & 51.4 & 37.2 & 21.74 & 315.7 & 99.3 & 3310.0 \\
\hline
\end{tabular}




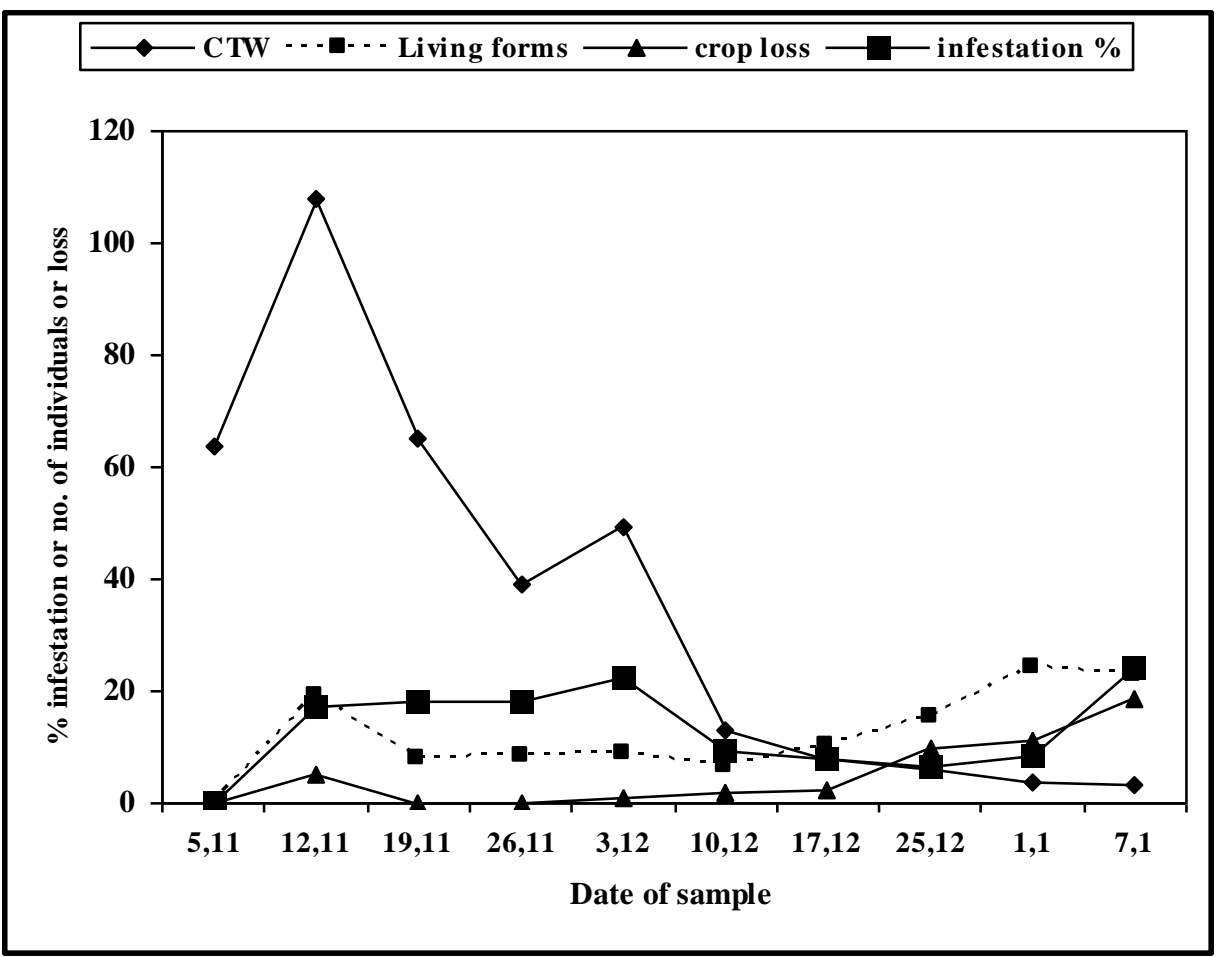

Fig. 1. Catch/trap/week, living stages, infestation percent and fruit loss in mandarin orchard infested by Ceratitis capitata in field cages experiment during 2006/2007 season.

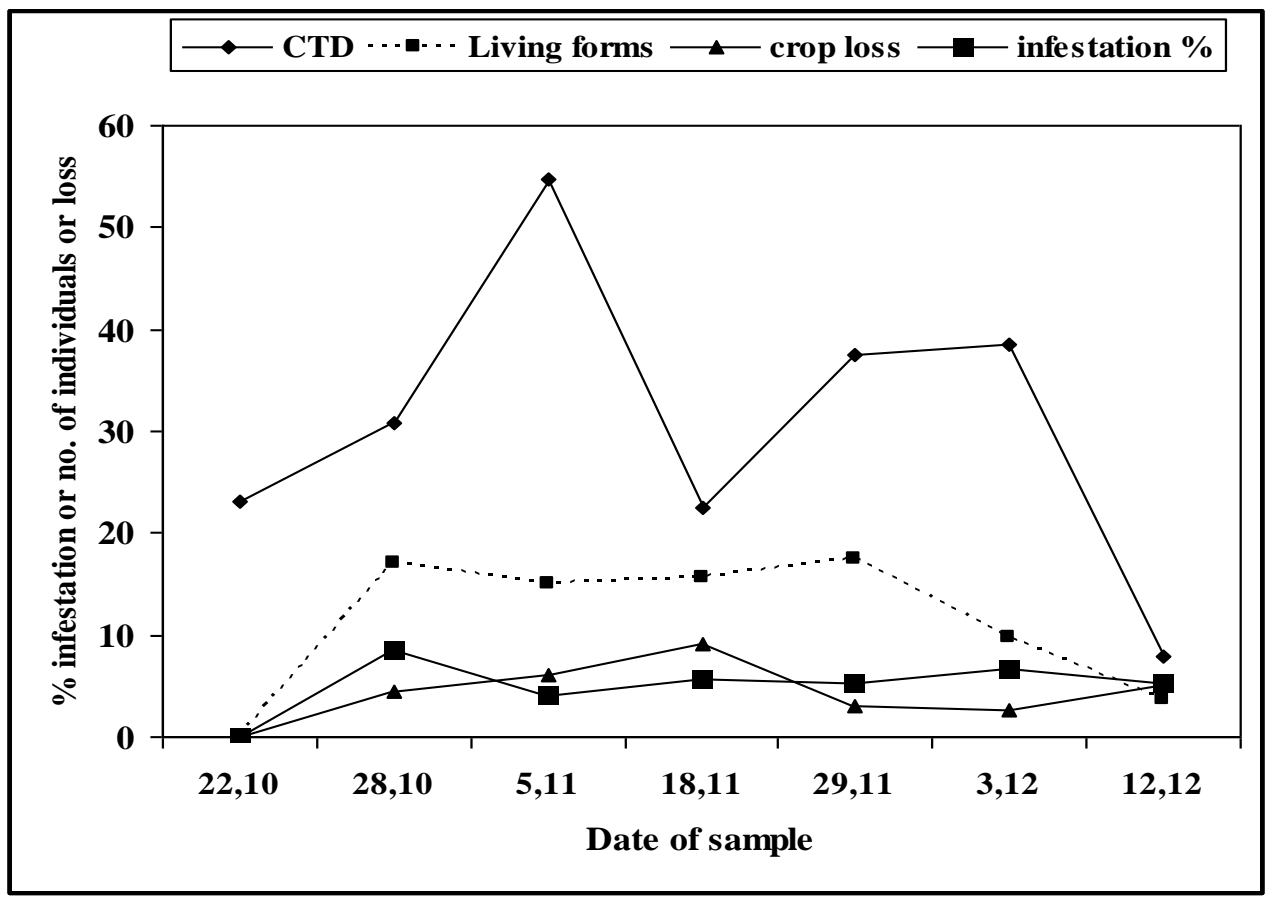

Fig. 2. Catch/trap/day, living stages, infestation percent and fruit loss in mandarin orchard infested by Ceratitis capitata in open orchard during 2007 season. 


\section{REFERENCES}

1. Compere, G. 1912. Seriousness of the mediterranean fruit-fly. Monthly Bull. Dept. Agric., Calif., 1, 4 : p. 143.

2. Hafez, M. and F. Fares. 1967. Annual number of generations of the Mediterranean fruit fly, Ceratitis capitata (Wied.) in U.A.R. Agric. Res. Rev., 45 (2) : 91-96.

3. Harris, E.J., S. Nakagawa and T. Uragos. 1971. Sticky traps for detection and survey of three tephritids. J. Econ. Entomol., $63: 62-65$.

4. Liquido, N.J., L.A. Shinoda and R.T. Cunningham. 1991. Host plants of the Mediterranean fruit-fly (Diptera: Tephritidae): an annotated world review. Miscellaneous Publication 77 Entomological Society of America, Ianham MD.

5. Snedecor, G.W. 1991. Statistical methods. The Iowa State College Press, Ames, Iowa. 


\title{
تأثير الإصابة بذبابة فاكهة البحر المتوسط على مستوى الضرر الاقتصادي

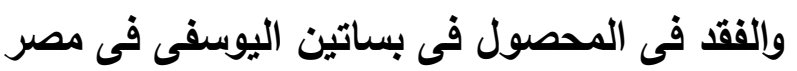

\author{
عايدة مصطقى الحكيم ، طلال صلاح الدين العباسى ، أحمد محمود زكى مسلم$$
\text { معهد بحوث وقاية النباتات - مركز البحوث الزراعية - الدقى - الجيزة }
$$

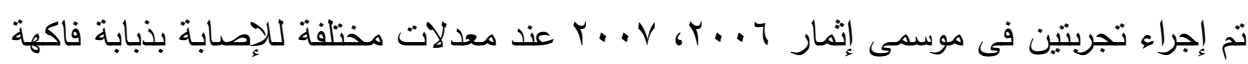

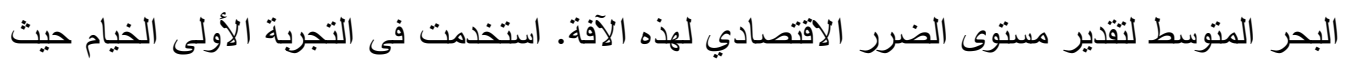
تم تغطية أربعة أثجار يوسفى ذات معدلات مختلفة للإصابة بخيام من القماش الخفيف مع استخدام دعامات خشبية. وتم تعليق مصيدة ورقية تحتوى على مادة لاصقة والجاذب الجنسى (تراى ميدلور)

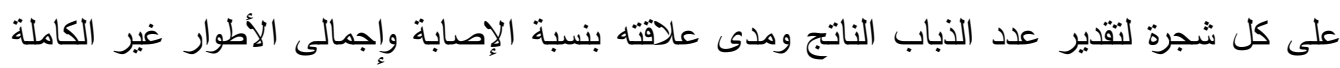

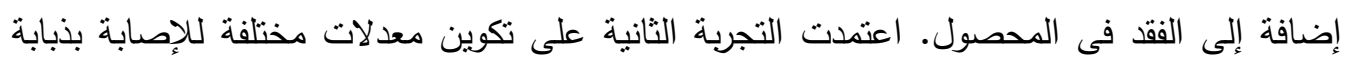
الفاكهة فى أثجار اليوسفى باستخدام الرش الجزئى فى قطاعات منساوية من البستان وتقدير العلاقة

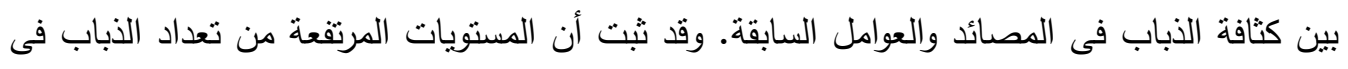

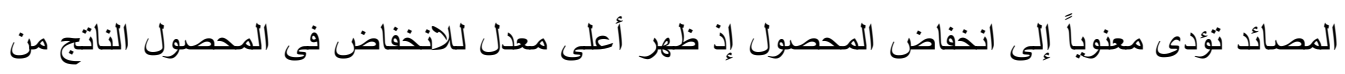
ثمار اليوسفى (ץ • 9 دولار/فدان) فى الجزء من البستان الذى لم تجرى به وسيلة مكافحة لذبابة فاكهة 